\title{
MEDICINE AND PNEUMATOLOGY: HENRY MORE, RICHARD BAXTER, AND FRANCIS GLISSON'S TREATISE ON THE ENERGETIC NATURE OF SUBSTANCE
}

by

\section{JOHN HENRY*}

The nature of the soul and its relationship to the body has always proved problematical for Christian philosophy. The source of the difficulty can be traced back to the efforts of the early Fathers to reconcile the essentially pagan concept of an immaterial and immortal soul with apostolic teachings about the after-life in which all the emphasis is placed upon the resurrection of the body. The tensions between these two traditions inevitably became strained during the sixteenth century when Protestant reformers insisted on a closer adherence to Scripture. Furthermore, even when leaving the problems of Scriptural hermeneutics aside, the dualistic approach to the question, in which soul (or spirit) and body are held to be categorically different in essence, had to overcome a number of intractable philosophical problems. So, it was not simply coincidence that when the new mechanical philosophy began to be formulated in a systematic way in the seventeenth century, it was couched in vigorously dualistic terms. In fact, three of the earliest fully elaborated systems of mechanical philosophy, those of Descartes, Digby, and Charleton, were explicitly intended to provide a philosophical prop for dualist theology. ${ }^{1}$ Moreover, it was because of its usefulness in promoting dualism that Cartesianism was first popularized in England not by a natural philosopher but by the Cambridge Platonist and theologian, Henry More. $^{2}$

*John Henry, MPhil, PhD, Wellcome Institute for the History of Medicine, 183 Euston Road, London NW 1 2BP.

${ }^{1}$ The literature regarding Descartes is vast but for a very recent treatment see Richard B. Carter, Descartes' medical philosophy: the organic solution to the mind-body problem, Baltimore Md., and London, Johns Hopkins University Press, 1983. Sir Kenelm Digby's intentions are made clear in the title of his new system of philosophy: Two treatises. In the one of which the nature of bodies; in the other the nature of mans soule is looked into: in way of the discovery of the immortality of reasonable soules, Paris, G. Blaizot, 1644. But see also John Henry, 'Atomism and eschatology: Catholicism and natural philosophy in the Interregnum', Br. J. Hist. Sci., 1982, 15: 211-239. Walter Charleton's major work, Physiologia Epicuro-GassendoCharltoniana, London, T. Newcomb for T. Heath, 1654, is described on the title-page as "the first part" and he announces his intention to write a second part on the nature of the soul at the end of the book, p.479. This never appeared in its intended form, but see W. Charleton, The immortality of the human soul demonstrated by the light of nature. In two dialogues, London, W. Wilson for H. Herringman, 1657.

2 Here again the literature is extensive, but all earlier works are effectively superseded by Alan Gabbey, 'Philosophia Cartesiana triumphata: Henry More (1646-1671)', in T. M. Lennon, J. M. Nicholas, and J. W. Davis (editors), Problems of Cartesianism, Kingston and Montreal, McGill-Queen's University Press, 1982, pp. $171-250$. 


\section{J. Henry}

In spite of this powerful support, however, there were still those who regarded the dichotomy between soul and body, so essential to dualism, as fundamentally inimical to any satisfactory explanation of psychosomatic interaction. Accordingly, monistic solutions to this problem also attracted some formidable advocates. Certainly, the greatest of these were the materialist Thomas Hobbes, the hylotheist Baruch de Spinoza, and the vitalist Gottfried Wilhelm Leibniz. But monistic pneumatology also found allies in a well-established tradition of medical thought. In a series of articles, D. P. Walker has shown the links between medical concepts of "spirit" and materialistic views of the human soul, while Walter Pagel has underlined the monistic pneumatology of two of the leading medical theorists in seventeenth-century England, William Harvey and Francis Glisson. ${ }^{3}$

The crucial nature of the ensuing debate between dualists and monists is revealed by the reaction of that champion of Cartesian dualism, Henry More. As is well known, More lost no time in publishing a detailed attack on Hobbes's De corpore (1655) in his The immortality of the soul (1659), and in the 1670s, he turned his attention to the new threats, Cartesian atheism and Spinozism. ${ }^{4}$ However, what has hardly been noticed before is that More also wrote a refutation of Francis Glisson's Tractatus de natura substantiae energetica (1672). ${ }^{5}$

Glisson's Treatise deserves recognition as one of the most original systems of philosophy to appear in the second half of the seventeenth century and as one of the most profound attempts to develop a monistic solution to the mind-body problem. One reason for the failure of intellectual historians to recognize its importance stems from the commonly held belief that it had absolutely no influence upon Glisson's contemporaries. The aim of this paper is to make a start towards correcting this erroneous view. Glisson's philosophy, as expressed in the Treatise, is rich, complex and

${ }^{3}$ D. P. Walker, 'The astral body in Renaissance medicine', J. Warburg and Courtauld Institutes, 1958, 21: 119-133; idem, 'Medical spirits in philosophy and theology from Ficino to Newton', in Arts du spectacle et histoire des idées. Recueil offert en hommage à Jean Jacquot, Tours, Centre d'Études Supérieures de la Renaissance, 1984, pp. 287-300; idem 'Medical spirits and God and the soul', in M. Fattori and M. Bianchi (editors), Spiritus. IV Colloquio internazionale del Lessico Intellettuale Europeo, Rome, 7-9 gennaio, 1983. Rome, Edizioni dell'Ateneo, 1984, pp. 233-244. The first two of these are now reprinted in D. P. Walker, Music, spirit and language in the Renaissance, London, Variorum Reprints, 1985. For related material see also D. P. Walker, Spiritual and demonic magic from Ficino to Campanella, London, Warburg Institute, 1958. On monism in Harvey and Glisson see Walter Pagel, 'Harvey and Glisson on irritability with a note on Van Helmont', Bull. Hist. Med., 1967, 41: 497-514; idem, 'The reaction to Aristotle in seventeenth-century biological thought', in E. A. Underwood (editor), Science, medicine and history: essars on the evolution of scientific thought and medical practice written in honour of Charles Singer, London, Oxford University Press, 1953, pp. 489-509; and idem, Joan Baptista van Helmont: reformer of science and medicine, Cambridge University Press, 1982, pp. 120-123.

${ }^{4}$ Henry More, The immortality of the soul so far forth as it is demonstrable from the light of nature. London, James Flesher for William Morden, 1659. For More's concern with Cartesian forms of atheism see Gabbey, op. cit., note 2 above; for his reactions to Spinoza see R. L. Colie, Light and enlightenment: a study of the Cambridge Platonists and the Dutch Arminians, Cambridge University Press, 1957: idem. 'Spinoza in England, 1665-1730', Proc. Amer. Philos. Soc., 1963, 107: 183-219, especially pp. 183-193; and Sarah Hutton, 'Reason and revelation in the Cambridge Platonists and their reception of Spinoza', in K. Gründer and W. Schmidt-Biggemann (editors), Spinoza in der Frühzeit seiner religiösen Wirkung. Heidelberg. Verlag Lambert Schneider, 1984, pp. 181-200.

${ }^{5}$ Francis Glisson, Tractatus de natura substantiae energetica, seu de vita naturae, eiusque trihus primis facultatibus, I. perceptiva naturalihus, II. appetitiva naturalibus, III. motiva naturalihus \& c.., London, E. Flesher for H. Brome and N. Hooke, 1672. 
subtle, and manages to be innovatory while drawing heavily upon scholastic traditions and Renaissance philosophical eclecticism. A full exposition of his philosophy has yet to be attempted and is not within the scope of this essay. ${ }^{6}$ Here, we will look at Glisson only as he appeared to Henry More and Richard Baxter, two of the leading contemporary English theologians, who explicity dealt with his theories. While considering the background to and the reasons for their interest in Glisson it will become clear that medical theories frequently had a profound influence on philosophy and theology in the early modern period. Before embarking on this, however, it is important to recognize the intimate connexion between Glisson's new system of natural philosophy and his medical concerns, and to this we will turn first.

\section{FRANCIS GLISSON'S MEDICAL PHILOSOPHY}

Glisson's output in print is not extensive, and there is a clear continuity of interests and themes running through his published works. The continuity is most clear between the Anatomia hepatis of 1654 and his next medical treatise, the Tractatus de ventriculo et intestinis of 1677. However, as Temkin and Pagel have pointed out, there are a number of notions employed by Glisson in his early efforts to understand the nature of rickets which foreshadow his later ideas. Temkin has traced Glisson's concept of irritability, most famously expounded in De ventriculo, to his description of the pulse in De rachitide: as the arteries thrust blood into the parts of the body there is a certain resistance which "provokes" or "irritates" the heart and arteries into increasing the pressure. A strong pulse will not be found, therefore, where resistance is low, as in the rachitic. Pagel, on the other hand, has pointed to Glisson's early use of the concept of "tension" or "tone" in the nerves to account for both sense and locomotion. By brooding on the notion of irritation and the role of the nerves in this process Glisson

\footnotetext{
${ }^{6}$ Glisson has been accorded a number of brief treatments, some of them very good, but he has not so far been considered more fully. An excellent starting place is Owsei Temkin's article on Glisson in the Dictionary of Scientific Biography (DSB) but consider also Pagel's papers cited in note 3 above and any of the following. Kurt Sprengel, Versuch einer pragmatischen Geschichte der Arzneikunde, 5 vols., Halle, J. J. Gebamer, 1803, vol. 5, pp. 105-109. C. Daremberg, Histoire des sciences médicales, comprenant l'anatomie. la physiologie, la médecine, la chirurgie et les doctrines de pathologie générale, 2 vols., Paris, J.-B Baillière. 1870, vol. 2, pp. 640-649 and 650-672; C.F.M. de Rémusat, Histoire de la philosophie en Angleterre depuis Bacon jusqu'à Locke, 2 vols., Paris, Didier, 1875, vol. 2, pp. 163-168; Owsei Temkin, 'The classical roots of Glisson's doctrine of irritation', Bull. Hist. Med., 1964, 38: 297-328; R. Milnes Walker, 'Francis Glisson and his capsule', Ann. R. Coll. Surg. Engl, 1966, 38: 71-91; Audrey B. Davis, 'Some implications of the circulation theory for disease theory and treatment in the seventeenth century', J. Hist. Med., 1971, 26: 28-39; idem, 'The circulation of the blood and chemical anatomy', in A. G. Debus (editor), Science, medicine and society in the Renaissance: essays in honour of Walter Pagel, 2 vols., New York, Science History Publications, 1972, vol. 2, pp. 25-37; Nikolaus Mani, 'Biomedical thought in Glisson's hepatology and in Wepfer's work on apoplexy', in Lloyd G. Stevenson (editor), A celehration of medical history, Baltimore Md., and London, Johns Hopkins University Press, 1982, pp. 37-63. Jeffrey Boss, '“Doctrina de circulatione sanguinis haud immutat antiquam medendi methodum". An unpublished manuscript (1662) by Francis Glisson (1597-1677) on implications of Harvey’s physiology”, Physis, 1978, 20: 309-336; and idem, 'Helmont, Glisson, and the doctrine of the common reservoir in the seventeenth-century revolution in physiology', Br. J. Hist. Sci., 1983, 63: 261-272. Perhaps it is also worth pointing out in this connection that Glisson himself said that the full details of his system were not worked out. He suggested that the Royal Society might be called upon to perfect and complete it. See Glisson, op. cit., note 5 above, Epistola dedicatoria (to the Earl of Shaftesbury), sig. alr. The present author is currently working on Glisson and his significance and hopes to add to this literature in the future; this essay is very much a preliminary sortie.
} 


\title{
J. Henry
}

was eventually led to his mature concept of irritability, in which all fibres in the body are said to be "irritable" even without the mediation of nerves.

Glisson's first prolonged efforts, in Anatomia hepatis, to define the nature of "irritability" as a biological phenomenon presupposed that nervous sensibility in the irritated part was a sine qua non. "All irritation", he wrote, "indicates the existence of perception", and that, in turn, indicates the presence of nerves. ${ }^{8}$ Glisson considered different kinds of "irritation" which could activate particular nerves and so lead to bodily changes or movements. The nerves responded to three kinds of activation: perception or sensation, appetite, and muscular movement. This, as Temkin has shown, was entirely in accord with Galen's teachings about the threefold purpose of the nerves: sensibility in the organs of perception, initiation of movement in the organs of locomotion, and in all other organs "the recognition of distressing things" (equivalent to Glisson's concept of appetite). ${ }^{9}$

Glisson developed these ideas in anatomical lectures delivered to the Royal College of Physicians shortly after the publication of his book on the liver. In his lecture on the brain, Glisson averred that its actions and uses consisted "in the exercise of its noble faculties, perception, appetite and motion". ${ }^{10} \mathrm{He}$ seems to have had no difficulty in locating the faculties of perception and appetite in the brain and he felt confident, therefore, in locating the motive faculty in the same organ:

For if it be the braine wch perceives, it must be the braine also wch desires $\&$ the same wch prosecutes that desire. For the desire were in vaine, if the braine had noe power to move toward a prosecution of the same, $\&$ there would be noe animall motion, if the braine had no power to command it. ${ }^{11}$

However, although Glisson was convinced that the motive faculty is located in the brain, he was all too aware of the difficulty of explaining the operation of this faculty:

\begin{abstract}
the manner how this power or faculty is put in execution, is soe obscure \& harde to be conceived, that the minde reflecting upon it selfe, cannot clearly trace its owne footstepps. It is hard indeed to follow the track of the idaea's [sic] from the outward senses to the braine, but much more difficult to trace the edicts of the braine back againe to the outward organs of motion, yet this in nature must be done. ${ }^{12}$
\end{abstract}

Abandoning all pretence to "a clear account of this", Glisson merely offered "some propositions about it". The first of these is that the brain could only excite the nerves to initiate motion by means of its own motion:

\footnotetext{
${ }^{7}$ F. Glisson, Anatomia hepatis, cui praemittuntur quaedam ad rem anatomicam universe spectantia et, ad calcem operis, subjiciuntur nonnulla de lymphae ductibus nuper repertis, London, O. Pullein, 1654: idem. Tractatus de ventriculo et intestinis. Cui praemittitur allius de partibus continentihus in genere; \& in specie, de iis abdominis, London, E. F. for Henry Brome, 1677; F. Glisson, G. Bates, and A. Regemorter, De rachitide. sive morbo puerili, qui vulgo the rickets dicitur, London, G. Du-Gardi for L. Sadler and R. Beaumont, 1650. I have used the English Translation of the latter, A treatise of the rickets: being a disease common to children, London, Peter Cole, 1651, see ch. 10, especially pp. 86-88, discussed in Temkin, op. cit., note 6 above. p. 294. and ch. 7, pp. 57-71 and ch. 14, pp. 144 150, discussed in Pagel (1967), op. cit., note 3 above, p. 499.

${ }^{8}$ Glisson, Anatomia hepatis, ch. 44, p. 397, and ch. 30, pp. 262 266. See Temkin, op. cit., note 6 above. p. 295; and B. L. Ullman, 'Glisson on gall bladder pain', J. Hist. Med., 1955, 10:112-113.

9 Temkin, op. cit., note 6 above, p. 302.

${ }^{10}$ British Library, Sloane MS 3306, f.157.

11 Ibid., f.163. Glisson discussed perception ff.157-62, ff.162-3, and motion ff.163 6 .

12 Ibid., f. 163.
} 


\title{
Medicine and pneumatology
}

For it is not conceivable, how the nerves should be excited, or they excite the muscles to worke according to the minde of the braine, if they were by no acte of the braine to give a signall to the nerves \& outward organs; that acte must be some kinde of motion in the braine itself. For the braine cannot move the nerves, either by its perception or appetite, because those are both immament actions \& cannot reache any thinge with out their owne subject. ${ }^{13}$

The second proposition was that the brain's "imperiall kinde of mandate" to the nerves "proceedes noe further, then to the grosse commande of such or such an action to be done".

\begin{abstract}
For a beast which also may make such an animall motion, knows not soe much, as that he hath a braine or nerves or muscles. Wherefore, the braine cannot give a particular command to every nerve or muscle, when it excites a motion. But it is content with the giving such a generall excitation, that such a motion may be made. And upon such excitation, the nerves excite the muscles propper, whereby the motion is affected. ${ }^{14}$
\end{abstract}

The role of the brain in initiating the movements of bodily parts now begins to look precarious, and its supremacy is hardly supported by Glisson's third and final proposition. Here, Glisson unwittingly attributed to the nerves a mind of their own, as it were, which enabled them to carry out "such a grosse command as that last before mentioned". So, "the nerves serving for every motion, may be sufficiently excited" while "other nerves, upon that excitation will not at all be stirred",

\begin{abstract}
because those nerves onely, which are propper to the action required, have learned by custome $\&$ long practice, that they are to move upon such a signal given, and the other nerves have in like manner bene accustomed to sitt still upon the same signall ... wherefore, I conclude, that the nerves learne to execute the dictates of the braine, upon the signall given, by custome and often experience. $^{15}$
\end{abstract}

Only a few folios earlier, Glisson had described how memory and learning were special attributes of the perceptive faculty, that "immanent action" which "cannot reache any thinge with out [its] owne subject". ${ }^{16}$ Small wonder, then, that Glisson's lecture on the brain and its three noble faculties breaks off abruptly at this point.

However, Glisson was not the only one to be confused about these matters. Even his mentor, the great William Harvey, had expressed contradictory ideas about the seat of perception in his De generatione animalium (1651). One moment Harvey implied that irritability depended on the mediation of the brain:

that which is plainly devoid of all sensation does not seem to be able to be provoked in any way or to be excited to move or initiate any actions. And we have no other sure sign by which we can distinguish an animate and sentient creature from one that is dead and senseless except by its movement which is provoked by some offensive object and which follows immediately upon the experience of this sensation and so proves the existence of sensation. But it is reasonable to discuss this matter further when we treat of the actions and use of the brain. ${ }^{17}$

13 Ibid.

14 Ibid., f.165.

15 Ibid., ff.165-6.

16 Ibid., f.163.

17 William Harvey, Disputations touching the generation of animals, translated by Gweneth Whitteridge. Oxford, Blackwell Scientific Publications, 1981, ch. 57, pp. 297-298. 


\section{J. Henry}

And yet, only a few paragraphs earlier, Harvey wrote about motions independent of the brain and other sensory organs:

Those motions and actions which the physicians call natural because they go on whether we will or no, and which we can neither moderate, accelerate, retard nor inhibit at our pleasure and are therefore independent of the brain, yet they are not performed without any sensation at all .... For whatsoever it is that by the diversity of its own movements strives against these things which provoke and molest it, must needs be endowed with sensation. ${ }^{18}$

Significantly, one of Harvey's examples of organs exhibiting innate sensitivity referred to the stomach and guts:

The stomach and guts attacked by bad humours, often stir up nausea, and belching, rumbling, vomiting and flux of the bowels, and it is not in our power to arrest these movements or to instigate them, and so I do not know of any sense depending on the brain which should excite those parts to actions of this kind. ${ }^{19}$

When Glisson decided to follow up his research into the anatomy and function of the liver, he chose as his subject the stomach and guts. It was during the course of this work that he developed his concepts of natural perceptions, appetites, and natural motility in all the fibres of the body even where no nerves were present. In developing these ideas, Glisson was able to draw not only upon various hints in Harvey, Galen, and Aristotle but also, as Pagel has shown, upon certain ideas found in the works of Joan Baptista van Helmont. In particular, the concept of nerves "learning" from experience whether to respond or not to a "grosse command" of the brain, which seemed so anomalous in his lecture on the brain to the Royal College, gave place to a general claim that all fibre in the body is capable of "learning" and "knowing" by virtue of its archeus or natural perception. ${ }^{20}$

By his own account, Glisson had completed his work on the stomach and intestines by 1662 but he held it back for fifteen years before publishing it. The reason he gave for this leaves us in no doubt as to the importance he placed upon his Treatise on the energetic nature of substance for a full understanding of his anatomical work. His first draft of De ventriculo "presupposed in many places (although also proving in many places) a general Natural Perception" which had not been written about anywhere. Consequently, "it seemed right", Glisson wrote, that the draft "should be postponed until I could produce and bring into the light another Treatise, forerunner to this, on the Life of Nature". ${ }^{21}$ According to a manuscript fragment, Glisson believed that the delay would amount to no more than two years, but clearly he was over-optimistic. "After the triall of a year or two I founde the worke so difficult", he said, "that it seemed to involve the whole body of natural physiology." 22 In the event, his

\footnotetext{
18 Ibid., pp. 296-297.

19 Ibid., p. 297.

${ }^{20}$ On the influence of Galen and Harvey see Temkin, op. cit., note 6 above; on the influence of Aristotle, see Pagel (1953), note 3 above; and on the influence of Harvey and Van Helmont see Pagel (1967), op. cit., note 3 above especially pp. 500-501 and 505, 508-509.

${ }^{21}$ Glisson (1677), op. cit, note 7 above, sig. A3r.

22 This fragment is a draft, in English, of the dedicatory epistle to the Earl of Shaftesbury. British Library. Sloane MS 574B, f.159v.
} 


\section{Medicine and pneumatology}

Tractatus . . de vita naturae appeared in 1672 , five years before the final version of $D e$ ventriculo. It is here that Glisson developed and expounded the notion that substance or matter itself has an "energetic nature" and a "life" which is primarily exemplified in those three "noble faculties" he once reserved for the brain: the perceptive, appetitive, and motive faculties.

Glisson clearly agreed with Harvey's sentiments expressed in De generatione, that the only way to distinguish between "an animate and sentient creature" and "one that is dead and senseless" was in terms of perception and the ability to move in accordance with those perceptions. ${ }^{23}$ The point of Glisson's De vita naturae, however, was simply to show that there was no such thing as "dead and senseless" matter. All matter, organic and inorganic alike, was endowed with life, Glisson insisted, and that life was defined in terms of an intrinsic motility which could be activated by inherent perceptivity and appetite (or aversion) within the matter itself. The difference, for Glisson, between what was usually considered to be non-living and living matter was simply one of organization. Provided matter was organized in a suitable way, the natural perception of matter could be "reduplicated" so that it perceived its own perception - giving rise to the sensitive nature of animals - and the vita naturae could be "duplicated" or "triplicated" to produce what we recognize as vegetable or animal life. The death of a plant or animal occurs upon the dissolution of this double or triple alliance. $^{24}$

Glisson's views on the nature of plant and animal life led naturally in his Treatise to a categorical rejection of the concept of a separate "substantial soul" in animals. This in itself, however, was not a radical departure from contemporary medical thinking: Cartesians too denied the existence of an animal soul, and Gassendists, like Walter Charleton and Thomas Willis, regarded it as a subtle material principle which dissipated on the death of the animal. Furthermore, Glisson was careful to point out that man was endowed with an immaterial rational soul which, being preternatural, fell outside the purview of his natural philosophy ${ }^{25}$ Nevertheless, in view of the vigorous monistic approach to the concept of life expressed in De vita naturae, it is easy to imagine that a contemporary reader might have been reminded of the opening words of Thomas Browne's Religio medici and thought them a suitable testament for Glisson himself: "For my Religion, though there be severall circumstances that might persuade the world I have none at all, as the generall scandall of my profession, the naturall course of my studies ...."26 In fact, much more research is needed before we can begin to assess the significance of the medical profession's reputation for irreligion and, in particular, Glisson's own attitude to religion. ${ }^{27}$ Nevertheless, we can see from Henry More's reaction to Glisson, examined below, that this leading theologian regarded Glisson's monistic philosophy as dangerously atheistic in tendency. So far, we know little of what Glisson's fellow physicians thought about De natura substantiae

${ }^{23}$ Harvey, op. cit., note 17 above.

24 Glisson, op. cit., note 5 above, especially 'Ad lectorem', section 11, sig. b2v-b3r, and ch. 18, section 5 , pp. $234-5$.

25 Ibid., 'Ad lectorem', sections 7 and 8, sig. a4v-blv.

26 Thomas Browne, Religio medici, London, Andrew Crooke, 1643. p.1.

27 There are indications of an interest in theology in Glisson's manuscripts: British Library, Sloane MS 3315, f.121-131 and Sloane MS 2251, f.117. A catalogue and index of Glisson`s papers is being prepared by Dr Jeffrey Boss and I am grateful to him for these references. 


\section{J. Henry}

energetica, but it is clear from More's attack upon him, and Richard Baxter's defence, that its importance and relevance was recognized beyond the bounds of the medical profession.

In conclusion, then, we can say that although the Treatise on the energetic nature of substance is Glisson's only philosophical work, it cannot therefore be dismissed as a mere curiosity. It was developed as an essential complement to his medical writings and fits perfectly naturally into the rest of his oeuvre. Having relied heavily, in the Anatomia hepatis, on a concept of irritability to account for the periodic expulsion of large amounts of bile from the gall-bladder into the intestine, Glisson subsequently believed that the dependence of irritability on the presence of nerves created more problems than it solved. His development of hints from Aristotle, Galen, Van Helmont, and Harvey and his own researches on the digestive system led him to formulate his concepts of natural perception, natural appetition, and natural motion intrinsic to all body fibres. And these in turn led him to work out the implications of these ideas for general matter theory. The end result, in the Treatise of 1672, is a complete system of natural philosophy dealing not only with organic but also inorganic matter and arguing for a materialistic vitalism which could be used to cut the Gordian knot of problems associated with Cartesian dualism by showing that all matter was intrinsically alive and endowed with faculties of perception, appetition, and self-motion.

\section{HenRY MoRe AND Medical IDEAS ABOUT LIFE AND THE SOUL}

The major intellectual endeavour of More's career was to combat the atheism which he perceived to be increasingly prevalent among his contemporaries (educated and uneducated alike). His earliest publications, therefore, constitute what has recently been called "an important philosophical programme" by which More hoped to prove the existence of God and the immortality of the soul. ${ }^{28}$ In fact, it was the nature of the immortal soul which occupied most of More's attention (beginning with his Platonicall song of the soul, 1642, and culminating with his Immortality of the soul in 1659) because a refusal to believe in an after-life, with its attendant notions of punishments or reward, was seen by More as likely to have the most drastic consequences on social behaviour. The "practical atheist", the libertine scoffer who had no religious and (ipso facto, according to More) no moral scruples, was the greatest threat to the smooth running of society because his behaviour was not constrained by the fear of post-mortem punishments.

These sort of people [More wrote] are very horribly afraid there should be any Spirit, lest there should be a Devil, and an account after this life; and therefore they are impatient of anything that implies it, that they may with a more full swing, and with all security from an after-reckoning. indulge their own Lusts and Humours in this. ${ }^{29}$

${ }^{28}$ Gabbey, op. cit., note 2 above, p. 222.

${ }^{29}$ The quotation is from ' $\mathrm{Dr}$. H. M. his letter, with the postcript to Mr J. G. . . ' which More included in his edition of Joseph Glanvill's Saducismus triumphatus or, full and plain evidence concerning witches and apparitions, London for J. Collins and S. Lownds, 1681, pp. 16-27, at p. 23. The Platonicall song of the soul can be consulted in Alexander B. Grosart (editor), The complete poems of Dr. Henry More (1614-1687), [Edinburgh University Press] for private circulation, 1878. The immortality of the soul, op. cit., note 4 above is more conveniently consulted in Henry More, A collection of several philosophical writings, London, James Flesher for William Morden, 1662, which is now reprinted, New York and London, Garland, 1978. 


\section{Medicine and pneumatology}

More elaborated his pneumatology, therefore, in an effort to provide the clearest and most forceful arguments for a personal after-life. ${ }^{30}$

In his attempt to give a comprehensive and definitive account of the nature of the soul, More realized that he could not confine himself merely to a discussion of Christian doctrines. In view of his reputation as a leading member of the Cambridge Platonists it is hardly surprising that he should also consider Platonist and neo-Platonist arguments. However, his consideration of current medical theories might seem, from our point of view, somewhat unexpected. But once we recognize the background to seventeenth-century pneumatology it becomes clear that More simply could not ignore medical theories. As D. P. Walker has shown, the eclectic neo-Platonism of the Renaissance gave rise to a number of confusions or contaminations between notions of spiritus, pneuma, and anima. Medical theories of "spirit" were especially likely to lead to such confusions, Walker has argued, because it was frequently invoked to bridge the metaphysical gap between body and soul, or matter and mind.$^{31}$ By the seventeenth century, there was a tradition, well established in spite of its potentially heretical nature, which tended to identify souls with medical concepts of spirit. ${ }^{32}$ This tradition could then be drawn upon by the early mechanical philosphers to explain those aspects of mental life which men share with animals. The Cartesian res cogitans was concerned only with abstract reasoning; all other aspects of human behaviour could be explained, analogously to animal behaviour, by the motions of animal spirits through the nerves and into the muscles. As Henry More summed it up:

the Glandula Pinealis is the common Sentient or Percipient of all Objects; and without a Soul, by virtue of the Spirits and Organization of the Body, may doe all those feats that we ordinarily conceive to be performed by Soul and Body joined together. For it being one ... and so handsomely seated as to communicate with the Spirits as well of the posterior as anteriour Cavities of the Brain; by their help all the motions of the Nerves (as well those that transmit the sense of outwards Objects, as of them that serve for the inward affections of the Body, such as Hunger, Thirst and the like) are easily conveighed into it; and so being variously moved, it does variously determine the course of the Spirits into such and such Muscles, whereby it moves the Body. ${ }^{33}$

\footnotetext{
Hereinafter I shall refer to this as More, Immortality. For a further account of More's attitude to post-mortem punishment see D. P. Walker, The decline of hell: seventeenth-century discussions of eternal torment, London, Routledge \& Kegan Paul, 1964, pp. 122-134. On the rise of concern about atheism during this period see G. E. Aylmer, 'Unbelief in seventeenth-century England', in D. Pennington and K. Thomas (editors), Puritans and revolutionaries, Oxford, Clarendon Press, 1978, pp. 22-46; John Redwood, Reason, ridicule and religion: the age of enlightenment in England, 1660-1750, London, Thames \& Hudson, 1976; Michael Hunter, Science and society in Restoration England, Cambridge University Press, 1981, p. 162-187; idem, 'The problem of "atheism" in early modern England', Trans. R. Hist. Soc., 5th Series, 1985, 35: 135-157.

${ }^{30}$ I have given a fuller account of More's pneumatology and the reasons for its extreme importance in his philosophical career in 'A Cambridge Platonist's materialism: Henry More and the concept of soul', $J$. Warburg and Courtauld Institutes, 1986, 49: 172-195.

${ }^{31}$ Walker, 'Medical spirits in philosophy ..., op. cit., note 3 above, pp. 287-289.

32 Ibid., p. 288; and idem, 'Medical spirits and God and the soul', op. cit., note 3 above.

${ }^{33}$ More, Immortality, p. 80. For fuller discussions of Cartesian mechanist biology see L. C. Rosenfield, From beast-machine to man-machine: the theme of animal soul in French letters from Descartes to La Mettrie, New York, Oxford University Press, 1940; P. R. Sloan, 'Descartes, the sceptics, and the rejection of vitalism in seventeeth-century physiology', Stud. Hist. Phil. Sci., 1977, 8: 1-28; and Carter, op. cit., note 1 above.
} 


\title{
J. Henry
}

As I have argued elsewhere, Walker is perfectly correct to suggest that these heretical materialist concepts of soul contaminate even More's own concept of the soul. ${ }^{34}$ However, if we ignore these philosophical inconsistencies then it is true to say that More is totally committed to a dualistic belief in the existence of incorporeal substances. Essentially, these incorporeal substances fall under three headings. There is God himself, of course, and there are two different kinds of "created spirits". There are, on the one hand, all the immaterial souls of men, angels, and demons; and on the other hand, there is a ubiquitous "Spirit of Nature" pervading even deep within the densest material body. Now, More ingeniously used the mechanical philosophy to establish the existence of these immaterial substances. His early admiration for Cartesian mechanism stemmed from his belief that Descartes had shown "the just extent of the Mechanical Powers of Matter, how farre they will reach, and where they fall short." It was the short-fall that was important for More, since it enabled him to bring in the Spirit of Nature which was held to be

\begin{abstract}
A substance incorporeal, but without Sense and Animadversion, pervading the whole Matter of the Universe, and exercising a Plastical power therein according to the sundry predispositions and occasions in the parts it works upon, raising such Phaenomena in the World, by directing the parts of the Matter and their Motion, as cannot be resolved into mere Mechanical powers. ${ }^{35}$
\end{abstract}

If More's enterprise in natural theology was to succeed, therefore, he had to defend the immateriality of the Spirit of Nature at all costs. If he conceded any corporeality in his hylarchic principle, his whole philosophy was in danger of reduction to materialistic mechanism and became indistinguishable from the atheistic philosophy of "the most able Advocate" of materialism, Thomas Hobbes. ${ }^{36}$ The Spirit of Nature, therefore, was used to explain various physical phenomena, such as the descent of bodies due to gravity, cohesion, condensation and rarefaction, magnetism, and various other phenomena which proved to be problematic for the mechanical philosophy. On biological and psychological questions, however, More did not want to rely on a universal spirit of nature since it might lead to another heresy: the denial of individual souls in favour of the Averroistic notion of a universal soul. ${ }^{37}$ The Spirit of Nature, then, gives place to individual souls in living creatures:

God is not the immediate Maker of these Bodies ... Nor, is it congruous to admit that the Plastick faculty of the Soul of the World [i.e. the Spirit of Nature] is the soul contriver of these fabricks of particular creatures (though I will not deny but she may give some rude preparative strokes towards Efformation;) but that in every particular World, such as Man is especially, his own Soul is the peculiar and most perfective Architect thereof, as the Soul of the Worlds is of it. ${ }^{38}$

\footnotetext{
${ }^{34}$ See note 30 above; and Walker, 'Medical spirits in philosophy', op. cit., note 3 above, p. 289, 294.

${ }^{35}$ More, Immortality, 13 and 193.

${ }^{36}$ Ibid., 43. On the contemporary reaction to Hobbes see S. I. Mintz, The hunting of Leviathan: seventeenth-century reactions to the materialism and moral philosophy of Thomas Hohbes, Cambridge University Press, 1970.

${ }^{37}$ On Averroistic notions of the soul see P. O. Kristeller, Renaissance thought and its sources, New York. Columbia University Press, 1979, pp. 181-196; and idem, 'Paduan Averroism and Alexandrism in the light of recent studies', in Renaissance thought II: Papers on humanism and the arts, New York, Harper \& Row, 1965. pp. $111-118$.

${ }^{38}$ More, Immortality, 102.
} 


\title{
Medicine and pneumatology
}

In the Scholia added to his philosophical works for the Latin Opera omnia of 1679, More delineated more carefully the spheres of influence of the Spirit of Nature and the soul. Subscribing to the Aristotelian belief that the soul is not infused into an embryo until its fortieth day, he argued that the "preparative strokes toward Efformation" of a foetus "are made by the Soul of the World, or by the Spirit of Nature", because

in Eggs, where the soul of the mother is not present, these first lineaments are formed before the coming in of the Soul of the Chicken, as being not yet organiz'd; But particular Souls are, according to Aristotle, the Actings of an organical Body. But the Punctum saliens, or Life point, discovers not any proper sense, but only Life when it withdraws itself from any hurtful touch: as neither do what we call the Plant-Animals which I do not take to live by any proper Soul, but through the Spirit of Nature, which hath either no Sense at all, or what is very dull. ${ }^{39}$

So, although the Spirit of Nature "assists in the very first beginnings of the Generation of Animals" it is superseded, in the higher animals at least, by the creature's individual soul. ${ }^{40}$ However, More's "main design" was not to distinguish between the Spirit of Nature and the soul but rather "to demonstrate that there is a Soul or Incorporeal Substance residing in us, distinct from the Body". 41 Accordingly, he was compelled to discuss critically various medical theories current at the time.

For example, in order to reserve for the immaterial soul (or for the immaterial Spirit of Nature in lower animals) the architectonic or organizing power of living creatures, More had to examine and reject a common alternative view. This was the remarkable idea that "the Sun and the Stars are the most Intellectual Beings in the world, and in them is that Knowledge, Counsel and Wisdome by which all Sublunary things are framed and governed". According to this view, the sun and stars

\begin{abstract}
by their several impresses and impregnations have filled the whole Earth with vital Motion, raising innumerable sorts of Flowers, Herbs and Trees out of the ground. These have also generated the several kinds of living Creatures. These have filled the Seas with Fishes, the Fields with Beasts, and the Aire with Fowles; the Terrestrial matter being as easily formed into the living shapes of these several Animals by the powerful impress of the Imagination of the Sun and Stars, as the Embryo in the womb is marked by the strong fancy of this Mother that bears him. ${ }^{42}$
\end{abstract}

Outlandish as this may seem to us, it was an extremely common notion in More's day. Similar arguments can be found in the work of Jean Fernel, Marsilio Ficino, Paracelsus, and even Robert Boyle. One of the ancient sources for this view is Aristotle's De generatione animalium: "the spirit which is contained in the foamy body of the semen ... is analogous to the element of the stars", and it is duly considered,

\footnotetext{
${ }^{39}$ This is taken from the English translation of the scholia which are included in the so-called "Fourth edition" of A collection of several philosophical uritings, London, Joseph Downing, 1712, p. 105 (of the Immortality, like the 1662 edition the treatises are separately paginated). This is called the fourth edition because the original separate works count as the first, the 1662 Collection as the second, and the Latin Opera omnia (see note 54 below) as the third. On the time of the infusion of the soul into the embryo see John T. Noonan jun, Contraception: a history of its treatment by the Catholic Theologians and Canonists, Cambridge, Mass., Belknap Press, 1965, pp. 89-90. The locus classicus is usually taken to be Aristotle, De hist. animal., VII, 3, 583b 2-5.

${ }^{40}$ It seems that More did not confine the concept of the immortal soul exclusively to humankind. On the immortality of animals see Immortality, 135-136.

${ }^{41}$ Ibid., 88 [mis-numbered as 78].

42 Ibid., 52.
} 


\section{J. Henry}

therefore, by that latter-day Aristotelian biologist, William Harvey, in his own De generatione. ${ }^{43}$ Nevertheless, More gave the idea short shrift. Donning his Cartesian hat, he insisted that

the sun and Stars have no immaterial Being residing in them, but are mere Matter consisting of the subtilest Particles and most vehemently agitated. For then we cannot but be assured that there is nothing in them more Divine than what is seen in other things that shine in the dark, suppose rotten wood, glo-worms or the flame of a rush candle.

And the idea that these heavenly bodies could form a creature like "the most curious Automaton that ever was invented by the wit of man" simply by "a mere Rectilinear impress upon the Aether down to the Earth" was dismissed as untenable. ${ }^{44}$

More dealt similarly with other theories which suggested that the soul or the organizing power of the body was merely a special kind of material substance. Drawing from the full range of current medical theories, he refuted in turn the suggestion that actuation and guidance of the body together with perception and the other functions of the common sense could be performed by the body as a whole, the orifice of the stomach, the heart, the brain, the septum lucidum, the pineal gland, "Regius his small and perfectly-solid particle", the spinal marrow, and the animal spirits. ${ }^{45}$ We need not consider each of More's arguments in any detail but it should be noted that the major thrust of his discussion was to deny that matter itself is sufficient to explain perception and sentience. "This absurd Principle", as More called it, gave rise to the belief "that Organization may doe strange feats":

as if they should imagine, that though neither Silver, nor Steel, nor Iron, nor Lute-strings have any Sense apart, yet being put together in such a manner and formed as will (suppose) make a complete Watch, they may have Sense: that is to say, that a Watch may be a living creature, though the several parts have neither Life nor Sense ... ${ }^{46}$

More was so confident that he could explode this notion that he actually put it forward as an axiom in order to show that Hobbes's "own acknowledged Principles will necessarily inferre the Existence of [immaterial substances] in the World." The twentieth axiom of The immortality of the soul reads:

\footnotetext{
${ }^{43}$ Aristotle, De gen. animal., 736b-737a; William Harvey, Exercitationes de generatione animalium, first published London, 1651, ch. 46. On Fernel see Sir Charles Sherrington, The endeavour of Jean Fernel, Cambridge University Press, 1946; on Ficino see Walker (1958) op. cit., note 3 above, especially pp. 3-59; for Paracelsus see Walter Pagel, Paracelsus: an introduction to philosophical medicine in the era of the Renaissance, Basle, Karger, 1982, especially pp. 117-125. On Boyle see L. Thorndike, A history of magic and experimental science, 8 vols., New York, Columbia University Press, 1923-1958, vol. 8, pp. 186-187. For a general treatment of "light metaphysics", the tradition of which these notions are a part, see A. C. Crombie, Robert Grosseteste and the origins of experimental science, 1100-1700, Oxford, Clarendon Press, 1953, pp. 104-134; and David C. Lindberg, Theories of vision from Al-Kindi to Kepler, Chicago, University of Chicago Press, 1976, 95-99.

44 More, Immortality, 53, 57.

45 Ibid., 77-94. As well as displaying a sound knowledge of various traditional therories of anatomical psychology, More also reveals here an awareness of recent theories propounded by J. B. van Helmont, Henricus Regius, and René Descartes. More, like Descartes, seems to have regarded Regius in particular as dangerously materialistic in outlook. See Nicolson (editor), op. cit., note 56 below, p. 389; and Sloan, op. cit., note 33 above, pp. 23-28.

${ }^{46}$ More, Immortality, 66, 77.
} 


\section{Medicine and pneumatology}

Motion or Re-action of one part of the Matter against another, or at least a due continuance thereof, is really one and the same with Sense and Perception, if there be any Sense or Perception in Matter. ${ }^{47}$

Of course, the conditional clause is crucial to More's case and it is just that which he then proceeded to deny. The absurdity of Axiom XX could be shown simply by pointing out that wherever there is motion so must there be sense and perception. In other words a dead carcass, a ringing bell, a bent bow, and "every Jack-in-a-box that School-boyes play with" would have to be "living Animals or Sensitive Creatures". Furthermore, on Hobbes's account, the communication of thoughts from one person to another can only take place by the justling of one interlocutor's animal spirits against those of the other, "as if men should knock heads to communicate to each other their conceits of Wit." 48

The essential point, then, of More's rejection of this mechanical account of perception is that matter is totally passive:

It is sufficiently manifest from sense and experience that Matter is a principle purely passive, and no otherwise moved or modified then as some other thing moves and modifies it, but cannot move it self at all. Which is most demonstrable to them that contend for Sense and Perception in it. For if it had any such Perception, it would by virtue of its Self-motion withdraw it self from under the knocks of hammers or fury of the fire; or of its own accord approach to such things as are most agreeable to it and pleasing, and that without the help of Muscles, it being thus immediately endowed with a Self-moving Power.

Matter, however, is "so stupid" that it lacks this Power of self-movement, as Hobbes, Descartes, or any strict mechanist would readily agree. ${ }^{49}$

Unfortunately for More, however, not everyone was a strict mechanist and subscribed to this concept of completely passive matter. As More's close associate, Ralph Cudworth, pointed out in his encyclopaedic survey of atheist philosophies, there were those who believed that matter was inherently active. The hylozoist, as Cudworth dubbed such a thinker, considered that all matter could move itself without muscles and that all matter could perceive and thereby could have a kind of sense without sensory organs or nerves. ${ }^{50} \mathrm{Cudworth}$ was not slow to realize that hylozoism was much more dangerous to religion than the mechanical materialism (or "Atomick Atheism") of a thinker like Hobbes,

${ }^{47}$ Ibid., 5, 59.

48 Ibid., 66, 86.

49 Ibid., 60. I use the term "strict mechanist" to refer to anyone who believed that matter was totally passive and inert. By no means all thinkers known to historians as mechanical philosophers were strict mechanists. I have argued elsewhere that the possibility of active matter was widely entertained among natural philosophers in seventeenth-century England: John Henry, 'Occult qualities and the experiemental philosophy: active principles in pre-Newtonian matter theory' Hist. Sci., 1986, 24: 335-381.

${ }^{50}$ Cudworth is not so careful to distinguish between perception and sensation as Glisson was. Sensation only occurs in "animate" matter, that is to say matter which is sufficiently organized to enable the simple or natural perception of matter to perceive its own perception. This perceptio perceptionis or reduplicated perception constitutes sensation. It seems that highly organized, or animate, matter is able to dispose itself in such a way as to provide itself with special organs of sensation. This requires detailed exposition and analysis, but for now see Glisson, op. cit., note 5 above, pp. 208-216; Pagel (1953), op. cit., note 3 above, pp. 505-507. 


\section{J. Henry}

For whereas the Atomick Atheism supposes the Notion or Idea of Body to be nothing but Extended Resisting Bulk, and consequently to include no manner of Life and Cogitation in it: Hylozoism on the contrary makes all Body, as such, and therefore every smallest atom of it, to have Life Essentially belonging to it (Natural Perception and Appetite) though without any Animal Sense or Reflexive Knowledge, as if Life, and Matter or Extended Bulk, were but two Incomplete and Inadequate Conceptions, of one and the same Substance, called Body. By reason of which life (not Animal but only Plastical) ... it is plain that there is no Necessity at all left, either of any Incorporeal Soul in Men to make them Rational, or of any Deity in the whole Universe to solve the Regularity thereof. ${ }^{51}$

Although Cudworth attached no names to the title hylozoist (apart from the ancient who allegedly founded the movement, Strato of Lampsacus), it is perfectly clear even from this brief extract that the Regius Professor of Hebrew had no one else in mind but the Reguis Professor of Physic at Cambridge, Francis Glisson. It was only Glisson who argued in print for the natural perception and the natural appetite of matter and who regarded life and matter as two conceptus inadequati of substance. ${ }^{52}$

So if in 1659 More could afford to dismiss the notion of sensitive and perceptive matter as "A thing so foolish and frivolous, that the mere recital of the opinion may well be thought confutation enough with the sober", after 1672 he was compelled to treat the idea much more seriously. For it was in that year that Glisson's Tractatus de natura substantiae energetica appeared. ${ }^{53}$

\section{Henry More and Francis Glisson}

Henry More returned to philosophical writing from more theological concerns during the preparation of his collected works, in Latin translations, for the so-called Opera omnia of $1679 .{ }^{54}$ More took the opportunity of the new edition to add scholia to his earlier philosophical works but he also published a number of short pieces for the first time. ${ }^{55}$ One of these new pieces, $A d$. V.C. epistola altera, was concerned to refute the thinker whom he considered to be the most dangerous atheist since Hobbes, Benedict de Spinoza. We know from a letter of More's to Anne, Lady Conway, that this little tract was composed hurriedly while the Latin collection of his works was

${ }^{51}$ Ralph Cudworth, The true intellectual system of the universe: the first part; wherein all the reason and philosophy of atheism is confuted; and its impossibility demonstrated, London, Richard Royston, 1678, p. 105.

52 The fact that Cudworth was attacking Glisson here has been noticed by Arrigo Pacchi, Cartesio in Inghilterra da More à Boyle, Roma-Bari, Editori Laterza, 1973, pp. 150-155. Cudworth's concern with hylozoism is discussed, but with no reference to Glisson, in John W. Yolton, Thinking matter: materialism in eighteenth-century Britain, Oxford, Basil Blackwell, 1984, pp. 4-13. See also Colie (1957), op. cit., note 4 above, pp. 117-144.

53 See note 5 above.

${ }^{54}$ Henry More, Opera omnia, tum quae latine, tum quae anglice scripta sunt; nunc vero Latinitate donata ..., 2 vols., London, J. Macock and R. Norton for J. Martyn and Gualt. Kettilby, 1679. The short title is often taken to include Opera theologica, anglice quidem primitus scripta, nunc vero per autorem latine reddita, London, J. Macock for J. Martyn and Gualteri Kettilby, 1675, as the first volume of three, but in my references I exclude this and treat the Opera omnia as a two-volume work.

55 These include a number of pieces on cabbalism (De usu decem Sephirotharum, Catechismus cabbalisticus, and Fundamenta philosophiae sive cabbalae aeto-paedo-melissaeae . . .), a refutation of Jacob Boehme's theology (Philosophiae teutonicae censura), and the attack on Spinoza (see following note) which concerns us here. For a brief but important discussion of the Cabbalae aeto-paedo-melissaeae see C. A. Staudenbaur, 'Platonism, theosophy and immaterialism: recent views of the Cambridge Platonists', J. Hist. Ideas, 1974, 35: 157-169, which corrects the thoroughly unsound S. Hutin, Henry More, essai sur les doctrines théosophiques chez les Platoniciens de Cambridge, Hildesheim, G. Olms, 1966. 


\section{Medicine and pneumatology}

actually in press. The letter also reveals that he began writing his refutation of Spinoza's Tractatus theologico-politicus even before he had finished reading the work. This is what he said to Anne:

I come thus late to London by reason of Cuperus his Confutation of Tractatus Theologicopoliticus which Monsieur Van Helmont gave me at Ragley from a friend in Holland, in quires, which while it was a binding at Cambridge I fell a reading Theologicopoliticus the better to understand Cuperus his confutation when it came from binding. But I found this Theologicopoliticus such an impious work, that I could not forbeare confuting him while a [sic] read him ... Proposing this Confutation of mine shall make up some part of this Philosophicall volumn. ${ }^{56}$

Spinozism, then, was regarded as a philosophical emergency which had to be treated immediately. The urgency of More's response stems in part from the fact that Spinoza, unlike Hobbes and the Cartesians, seemed to argue that matter is inherently active and "alive". This approach, More could hardly fail to recognize, completely undermined his previous attempts to establish the existence of incorporeal animating spirits, all of which were based on the Hobbist or Cartesian assumption that matter is completely passive and inert. It was during the course of his response to Spinozistic "living" matter that More paused in order to reject Glisson's arguments for the "energetic nature of substance". He took his cue from his fellow anti-Spinozist, Franciscus Cuperus:

So when Cuperus says that modern atheists nowadays believe in the innate life of matter, not in a mechanical mover, he gives a nod to some such hypothesis as the most distinguished Doctor Francis Glisson attempted to describe, with very accurate and clear arguments, in his Treatise de Natura Substantiae Energetica, or, de Vita Naturae. Whereas Spinoza contends that substance, in so far as it is substance, exists $a$ se, indeed is that which subsists by itself so he [Glisson] holds that substance, qua substance, lives by the necessary power of its Nature, that is, it perceives, it desires and it moves itself [percipere, appetere, seseque movere]: which faculties; perceptive, appetitive and motive; he holds, accordingly, to be immediately present in matter itself. ${ }^{5 \dagger}$

There follow eight closely argued folio pages against Glisson's philosophy and what More saw as its atheistic implications. It is clear from these pages that More had given close attention to Glisson's Tractatus, and it is easy to see why. Glisson took the concept of inherently active matter further than any of his contemporaries, including Spinoza.

Since Glisson believed that the energetic nature of substance was the internal principle of movements in matter he tried to take evidence for his case "from various motions observed in Nature". Glisson understood the word "motion", in the

\footnotetext{
${ }^{56}$ Henry More to Anne, Lady Conway, 3 April [1677], in Marjorie H. Nicolson, Conway letters: the correspondence of Anne, Viscountess Conway, Henry More, and their friends, 1642-1684, New Haven, Conn., Yale University Press, 1930, p. 429. Franciscus Cuperus [Frans Cuiper] (1629-92) published a refutation of Spinoza under the title, Arcana atheismi revelata, philosophice et paradoxe refutata examine Tractatus Theologico-Politici, Rotterdam, Isaac Naeranus, 1676. For a discussion of this work and its author see Colie, op. cit., note 4 above, pp. 74-75, 97-116. More's "confutation" of Spinoza appeared in volume 1 of the two-volume Opera omnia (see note 54 above), as Ad V.C. epistola altera quae brevem Tractatus Theologico-politici confutationem complectitur, paucaque sub finem annexa habet de libri Francisci Cuperi scopo, cui titulus est, Arcana Atheismi revelata, pp. 565-614. The identity of V.C. still engages scholarly speculation: there is a footnote about it in Gabbey, op. cit., note 2 above, pp. 214-215; and see also Paolo Cristofolini, Cartesiani e sociniani: studio su Henry More, Urbino, Argalia Editore, 1974, pp. 139-141. Cristofolini also reprints the latin text of $A d V$.C. epistola altera, pp. 139-206.

${ }^{57}$ More, Opera omnia, 1: 601. Glisson is mentioned on p. 601 and examined in detail pp. 604-611. Translations from this are mine.
} 


\section{J. Henry}

Aristotelian sense, to mean "change" and so a number of his examples of motion may seem unfamiliar to us. Not only did he argue from the motion "of the Heavens and Planets and even the Earth itself around the Sun", the motions caused by horror vacui and "the motion of Rarefaction and Condensation" but also from "the motion of solidity" [motus Antitypiae], "the motion of coherence" [motus nexus], and "the motion of freedom" [motus libertatis] (by which he meant the elastic tendency of a compressed body, say, to return to its former state when external pressure is removed). ${ }^{58}$ Henry More attempted to refute each of these in turn. The resistance or solidity of matter cannot be used to prove the vitality of matter, he insisted, because "substance qua substance" is sufficient to explain solidity. By which, presumably, he meant that solidity is part of the definition of matter. ${ }^{59}$ Elsewhere he called upon the mechanical philosophy in an effort to show that Glisson's vitalism was an unnecessary hypothesis. The coherence of matter can be explained more simply (so More believed!) in terms of Cartesian circular motion, the plenum, and the non-interpenetrability of matter. Similarly, "the Motus Coelorum, that is, the Vortexes, does not indicate any perceptive life in the matter of the vortexes, since such a portion of motion is impressed on them mechanically, or much more likely by some immaterial principle, that they revolve freely in these gyrations entirely without self-perception." ${ }^{60}$ Needless to say, the immaterial principle alluded to here is More's "Spirit of Nature", and he invoked that in his rejection of all Glisson's other examples of different kinds of motion. "The parts of matter", for example, "cohere and are connected by the one universal bond of the Spirit of Nature which holds together and actuates the whole material world." It is the hylarchic principle, then, which accounts for fuga vacui and for motus libertatis. When air is caused to expand by heating, for example, it is merely due to increased vibration of the particles and, on cooling, the air returns to its former volume "not by its own power but by virtue of the Universal Hylostatic Spirit." 61

58 I am paraphrasing, and quoting from More's account of Glisson's theories. See More, Opera omnia, 1: 605-606. In fact, More was simplifying Glisson's account. Glisson distinguished between perpetual and non-perpetual motions. The perpetual motions are motus antitypia, motus nexus and motus corporum coelestium and they are discussed in the Tractatus, note 5 above, pp. 352, 354 and 355 respectively. Non-perpetual motions are more complicated and less clear. At ch. 25 (pp. 356-363) we learn that there are three kinds of non-perpetual motion depending on whether the motive principle is internal, external, or a mixture of both. In order to establish his claims about the innate motility of all matter, Glisson discounted the first of these (which is not in contention) and turned his attention to the last two kinds which he called, in keeping with the common opinion, "inanimate". Inanimate motions are divided into five classes which embrace the other examples of "Species" of motion which More singled out. Motus libertatus is discussed at p. 375, motus condensatione et rarefactione at p. 376, fuga vacui at p. 367, but see also p. 432.

${ }_{59}$ More, opera omnia, 1: 605.

${ }^{60}$ Ibid.

${ }^{61}$ Ibid., p. 606. More used similar arguments, employing the Spirit of Nature to account for phenomena which could be explained perfectly adequately without it, in his Enchiridion metaphysicum: sive de rebus incorporeis succinta \& luculenta dissertatio. Pars prima: de existentia \& natura rerum incorporearum in genere, London, E. Flesher, 1671. Consequently, he had already attracted the attention of the two leading experimental philosophers in England, Robert Boyle and Robert Hooke, both of whom repudiated his ideas in print. See Robert Boyle, An hydrostatical discourse occasion'd by some objections of Dr. Henry More against some explications of new experiments ..., London, for Richard Davis, 1672; and Robert Hooke, Lampas: or, descriptions of some mechanical improvements of lamps and waterpoises..., London, John Martyn, 1677, reprinted in R. T. Gunther (editor), Early science in Oxford, 15 vols., Oxford, [for the author], 1923-1967, vol. 8 (1931), pp. 182-195. In spite of this and another polemic on the same issue with the scientific virtuoso, Sir Matthew Hale, More remained recalcitrant. I have examined More's relationship with 


\section{Medicine and pneumatology}

More's "confutation" of Glisson's internal principles of motion, philosophically unsatisfactory though it is, stands representative of all his arguments. He never met Glisson on his own terms but was merely content to assert that everything Glisson used to support his case actually supported the existence of the Spirit of Nature. Glisson's arguments, More somewhat petulantly insisted, "do not prove that life emanates from matter itself or that life is not communicated to it by an immaterial Principle". The point is, of course, that More was driven by his theological concerns to beg the very questions that really divided him from Glisson. At one highly significant point in his discussion More let the reason for his anxiety show: "This argument [that internal motion is a sufficient principle of life] cannot prove that matter is autozoon [self-living] and endowed with perceptive and appetitive life, unless it is previously supposed that there is no God who can create a Spirit purely Plastic and set it over the matter of the world." 62

According to More, then, this vitalist way of arguing was even more dangerous than Hobbist mechanism. Glisson actually seemed (by implication) to take providence out of God's hands and to implant that too directly within matter when he asked "Is Nature so far fortuitous that it begins a new operation of its own record without any purpose to itself? or does it rather manage all things wisely and not without admirable providence?"63 It was speculations like these which led More to denounce Glisson's philosophy in the strongest terms: "Only those who deny God and all incorporeal substance; strive to seek the origin of motion and all life which gleams in the universe in matter itself." 64

More clearly announced that Glisson's philosophy "should certainly carry some weight with those who deny any substance beyond body. For, then it may be reasonable enough to decide that a kind of life is immediately and primaevally present in matter, whose characteristic properties of life; which are thought to be, and are called 'souls' by the vulgar; are only various modifications of matter ...."65

More agreed, therefore, with Franciscus Cuperus that "modern atheists . . . having forsaken mechanical reasons for the created world, take up [a belief] in the primitive life of matter." 66

these and other natural philosphers in a forthcoming paper entitled 'Henry More $v$. Robert Boyle: the Spirit of Nature and the nature of Providence'.

${ }^{62}$ More, Opera omnia, 1: 607 .

${ }^{63}$ Ibid. This is a quotation from Glisson's ch. 17, sect. 3 (as More tells us). It is to be found in Glisson. op. cit., note 5 above, p. 226. The point of Glisson's rhetorical questions was to affirm that matter must have perception and appetite: "I am unable to conceive how it happens that motion arises purely from an internal principle, yet that principle neither desires nor perceives."

${ }^{64}$ More, Opera omnia, 1: 607.

65 Ibid., p. 608.

${ }^{66}$ Ibid. See also p. 611 where More concluded that the "modern atheists", of whom Cuperus speaks, "who profess a vital principal in the created World, but because of life arising from matter itself, and who do not believe that there is anything in nature beyond this living matter, can scrape together for themselves nothing from the writings of Glisson by which they very greatly support their cause." I should point out that the charge of atheism was an extremely serious one at the time and, consequently, More pointed out that Glisson "not only acknowledges but so often insists upon the existence of the Creator God and other incorporeal substances", p. 607. As we shall see, it is perfectly possible to propound a natural philosophy like that of Glisson and still remain within the traditions of voluntarist theology. 


\section{J. Henry}

It seems likely, then, that it was More's obsessive fear of atheism which inhibited his philosophical analysis of Glisson's Tractatus and prevented him from providing any really cogent counter-arguments. More's response is best characterized as merely a series of desperate reiterations of the role of the Spirit of Nature in the fabric of the World. Consider this final example:

it is thoroughly manifest that the most learned Glisson has put forward no argument of any import, neither a priori nor a posteriori, which might prove the Energetic Nature of Substance ... since those patterns of life which seem to appear in matter could be brought about by some immaterial Principle. ${ }^{67}$

What is worse, More compounded this kind of unsatisfactory procedure with an exercise in question-begging of astonishing impudence. The principle which More invoked (against Glisson) to account for movements, perception, and other "patterns of life" must certainly be immaterial, More brazenly insisted, "because it dictates each of the motions of Matter". ${ }^{6}$

\section{In DEFenCe of Glisson: Richard Baxter's POlemic With MoRe}

We would be making a serious mistake if we assumed that More's attack on Glisson as a comforter of atheists represented any kind of consensus. Writing at a time when there was little consensus among theologians in general, More was regarded by a number of his contemporaries as precariously idiosyncratic. ${ }^{69}$ But what is significant

${ }^{67}$ More, Opera omnia, 1: 608 .

${ }^{68}$ Ibid. More's failure to confront Glisson's arguments and his monotonous reminders of the existence of a "Spirit of Nature", which he claimed to have proved in his earlier writings, clearly testify to the intense fear of atheism that gripped him. But I think the marked intensity of More's commitment to the dualist distinction between matter and a preternatural actuating principle also illustrates an important insight to be found in R. S. Westfall, Science and religion in seventeenth-century England, New Haven, Conn., Yale University Press, 1958. Westfall, speaking of seventeenth-century natural theologians, said that "Despite the natural piety of the virtuoso, the scepticism of the Enlightenment was already present in embryo among them" (p. 219). The origins of their doubts, Westfall suggested, lay in the many objections to traditional religion, "which were too close to their own beliefs to be ignored" (p. 145). In developing their natural theologies, therefore, "More than answering hypothetical atheists, they were trying to satsfy their own doubts" (p. 145). More was not a man who suffered from doubts but he was all too aware of how close Glisson's ideas were to his own. Indeed, at one point, More said of Glisson: "If he had put for 'Nature' the 'Spirit of Nature' that would have been enough for us to agree" (Opera omnia, 1: 606). The closeness of Glisson's ideas to those of More and Cudworth have also been noticed by Owsei Temkin (see his article in $D S B, 5: 426-427$ ). And yet, no matter how close they seem, the difference between them is absolutely crucial. Perhaps More felt that by expounding Glisson's arguments in order to refute them he would stimulate more interest in them. He certainly felt that he had made this kind of error before. As he wrote to Robert Boyle on 4 December 1671, "I have, from my very first letters to Descartes, till this last book of mine, always expressed my opinion, that this mechanical way would not hold in all phenomena, as I always verily thought: but this would not save us from being accounted amongst the wits, one of their gang: and a perfect Cartesian, ... and, indeed, no less than an infidel and an atheist", in Robert Boyle. The works, 6 vols.. London, J. \& F. Rivington, L. Davis, et al., 1772, vol. 6, p. 513. In Glisson's case, then, More chose not so much to refute it as to pronounce it to be wrong. For a further discussion of similarity between More's and Glisson's ideas see Henry op. cit., note 30 above.

${ }^{69}$ The fullest discussion of More's unorthodoxy is to be found in Samuel Parker, A free and impartial censure of the Platonick philosophie. Oxford. W. Hall for Richard Davis, 1666, especially pp. 79-83. Boyle. op. cit., note 61 above, referred to More's Principium Hylarchicum as a "precarious Principle" in theology as well as natural philosophy, as did Sir Matthew Hale. Ohservations touching the principles of natural motions; . . . together with a reply to certain remarks touching the gravitation of fluids, London, W. Godbid for W. Shrowsbury, 1677, p. 282. Moreover, More felt the need to defend his ideas not by recourse to 
for our discussion is the fact that just two years after the appearance of More's $A d$. V.C. epistola altera Glisson's name appeared once again in a theological context; but this time he was cited with approbation. Richard Baxter, in his Methodus theologiae christianae (1681), deferred twice to Glisson. Once, in the preface, on the subject of the active principle in nature, and once on the subject of "Virtus activa vitalis". 70 The precise meanings of these references are (at least to this reader) somewhat obscure but, fortunately, Baxter expanded his views on active principles and on Glisson's De natura substantiae energetica in a letter to Henry More written in the same year. It was written at More's request because "It seemed good to the worthy Dr. to desire my thoughts of his Description of a Spirit, which he laid down in the first Edition of Mr. Glanvile of Apparitions". ${ }^{71}$ The fact that More published a long reply to this private letter (in the second edition of Glanvill's History of apparitions) is powerful testimony to More's sensitivity to criticism on this issue and of his protectiveness towards his concept of spirit. This reply, entitled $A$ letter to a learned psychopyrist, appeared early in 1682; whereupon, within months, Baxter published his original letter, together with a defence of it in a discourse $O f$ the nature of spirits. However, the last word on the matter went to More (again a sign of the importance More attached to his own style of pneumatology), this time writing as the anonymous commentator on Bishop Rust's Discourse of truth. ${ }^{72}$ This polemic, so far completely overlooked, contains a good deal of interest for the intellectual historian but, for the sake of brevity, we will confine ourselves here to those parts of the dialogue which involve Glisson. ${ }^{73}$

philosophical argument but by Scriptural exegesis in his The apology of Dr. Henry More, London, J. Flesher for W. Morden, 1664. See also, M. H. Nicolson, 'Christ's College and the latitude-men', Mod Philology., 1929, 27: 35--53.

${ }^{70}$ Richard Baxter, Methodus theologiae christianae .... London, M. White and T. Snowden, 1681, sig. A5r., p. 177.

${ }^{71}$ Richard Baxter, Of the immortality of mans soule, and the nature of it, and other spirits. Two discourses: one in a letter to an unknou'n doubter; the other in a reply to Dr. Henry. More's animadversions on a private letter to him; which he published in his second edition of Mr. Joseph. Glanvil's Sadducismus Triumphatus, or history of apparitions, London, for B. Simmons, 1682, Sig. a4r. See note 29 above for full citation of the first edition of Glanvill's Saducismus; the second edition, which includes More's 'Letter to a learned psychopyrist', appeared in the first months of 1682 (new style). More's first letter to Baxter soliciting his opinion on the concept of spirit is extant in the Baxter MSS at Dr Williams's Library, Baxter Letters, III, f.286 (it is dated 25 September 1681).

72 Joseph Glanvill [and George Rust], Two choice and useful treatises: the one Lux Orientalis or an enquiry. into the opinion of the eastern sages concerning the praeexistence of souls. Being a key to unlock the grand mysteries of providence, in relation to mans sins and misery. The other a discourse of trut $h, b y$ the late Reverend Dr Rust Lord Bishop of Dromore in Ireland. With annotations on them both, London, for James Collins and Sam Lowndes, 1682. More's annotations on Rust have a separate title page which reads: Annotations upon the discourse of truth into which is inserted by way of digression, a brief return to Mr. Baxter's reply, which he calls a placid collation with the learned Dr. Henry More, occasioned by the Doctors answer to a letter of the learned psychopyrist .... The digression is found pp. 180-246. Hereinafter cited as More. Digression. The annotations are unsigned but they are almost certainly by More. See Nicolson, op. cit., note 56 above, p. 173 ; and Walker, op. cit., note 29 above, 126, 131 .

${ }^{73}$ The only other discussion of this polemic which I am aware of considers it in the broader context of late seventeenth-century discussions of the nature of spirit: Robert Crocker. 'An intellectual biography of Henry More, 1614-1687', ch. 8 of a thesis to be presented at Oxford University for the DPhil. I am grateful to Mr Crocker for allowing me to read this prior to submission. One of the few historians to embark on a serious study of Richard Baxter in recent years is William M. Lamont but even he failed to notice this polemic. More subsequently accused Baxter of writing against his views on the Apocalypse as revenge against More's "booke of spirits". Lamont points this out but he seems entirely unaware of their earlier polemic. See W. M. 
The reason for More's initial concern to refute Baxter's private letter on the nature of spirits is made clear in a letter to Baxter of February 1682. A "psychopyrist", More explained to Baxter, is a thinker who "would make all created Spirits a kinde of fire" and this popular opinion is the only serious threat remaining to "the most true and useful notion of a Spirit", namely More's own. There can be no doubt of the extreme importance he attached to the issue:

That the world should have a true, easy and useful notion of a Spirit I look upon it to be a thing of exceeding great consequence which made me take this opportunity of settling it by this confutation of the Psychopyrists in my Answer to your letter as I did by the confutation of the Holenmerians and Nullibists in my short Treatise of the True Notion of a Spirit. ${ }^{74}$

Turning to Baxter's letter we can readily agree with More that this author had "closely and compactedly ... couched therein the ... strengths of what they have to say for themselves that are Psychopyrists." ${ }^{75}$ For example, Baxter wrote that

\begin{abstract}
Though I run not into the excess of Ludov. Le Grand de Igne (nor of Telesius or Patricius) ${ }^{76}$ I would Ignis were better studied: But this Room will not serve me to say what I think of it. But in brief, He that knoweth that Ignis is a Substance, whose Form is the Potentia activa movendi illuminandi, calefaciendi, these as received in a gross Passive Body, being but their Accidents oft, but the Igneous Substance in act operating on them, and conceiveth of Spirits, but as Ignis eminenter, that is, of a purer substance; than Ignis is, which we best conceive of (next the Formal Virtue) by its similitude, I think knows as much as I can reach of the Substance of Created Spirits. And the Greek Fathers that called Spirits Fire, and distinguished Ignem per formas into Intellective, Sensitive and Vegetative or Visible Fire, (as it is in Aere Ignito) allowing an Incomprehensible Purity of Substance in the higher above the lower (as in Passives Air hath above Water, \&c.). I think did speak tolerably, and as informingly as are the notions of Penetrability and Indivisibility; though perhaps these also may be useful. ${ }^{\text {t7 }}$
\end{abstract}

Lamont, Richard Baxter and the millennium: Protestant imperialism and the English Revolution, London, Croom Helm, 1979, p. 45. For a further indication of the extent of More's annoyance about Baxter's critique of his notion of spirits consider the following: "I shall only name one Disingenuity more, which was antecedent to them all, and gave occasion both to Mr. Baxters Letter, and to the Doctors Answer thereto, and to this Reply of Mr. Baxter. And that was, That Mr. Baxter in his Methodus Theologiae (as he has done also in a little Pamphlet touching Judge Hales) without giving any reasons, which is the worst way of traducing any man or his sentiments, slighted and slurred those two essential Attributes of a Spirit. Penetrability and Indiscerpibility, which for their certain Truth and usefulness the Doctor thought fit to communicate to the World", More Digression, p. 202. Baxter's comments on the nature of spirit in his 'Pamphlet touching Judge Hales' (see note 95 below) may be consulted in Sir Matthew Hale, The works. moral and religious .... London, H. D. Symonds et al., 1805, pp. 95-100. Here also Glisson`s theories are invoked (p. 99).

${ }^{74}$ More to Baxter, February 10 1681/2, Dr Williams`s Library, Baxter Letters, vol. III, f. 284. I am grateful to the Trustees of Dr Williams's Library for allowing me to consult and quote from the Baxter Letters. More was referring in this letter to his The easie, true, and genuine notion and consistent explication of the nature of a spirit ..., which is an English translation of the last two chapters (27 and 28) of the Enchiridion metaphysicum (note 61 above), and which was included in Glanvill, op. cit., note 29 above. "Holenmerians" are those who believe that the soul can be tota in toto et tota in qualibet parte while "nullibists" are those. like Descartes, who believe that souls are non-spatial entities and so, in More's terms, "nowhere".

${ }^{75} \mathrm{Dr}$ Williams's Library, Baxter Letters, vol. III, f. 284.

${ }^{76}$ I have been unable to trace Lodov. Le Grand and his book De igne. For brief accounts of Telesio and Patrizi see P. O. Kristeller, Eight philosophers of the Italian Renaissance, Stanford University Press, 1964.

${ }_{77}$ Baxter, Of the nature of spirits, op. cit., note 71 above [the second of the Two discourses, separately paginated], sig. A5r/v. In his Letter to a learned psychop!rist, op. cit., note 71 above, More indicates that he does not know which Greek Fathers Baxter had in mind, p. 234. Neither do I, but for indications of the background to similar ideas see, for example. the articles by Walker cited in note 3 above; and Everett Mendelsohn, Heat and life. the development of the theory of animal heat. Cambridge. Mass.. Harvard University Press, 1964. 


\section{Medicine and pneumatology}

So, Baxter regarded fire as "a Substance permeant and existent in all mixt Bodies on Earth ... in your Blood it is the prime part of that called the Spirits, which are nothing but the Igneous Principle in a pure aerial Vehicle and is the Organ of the Sensitive Faculties of the Soul" ${ }^{78}$ Clearly, Baxter would agree with Richard Lower (to take one example from many like-minded physiologists) that "the blood in its course through the arteries is like a flaming fire." Once again we can see the profound influence of medical ideas about spirits and the nature of the soul on a leading theologian. ${ }^{79}$

Among such general indications of a familiarity with current medical thinking in Baxter's discourse on the soul we also find numerous specific references to Glisson. In view of the frequency of these references and Baxter's failure to name any other medical writer (unless we count a passing reference to Daniel Sennert on page 18), it is safe to assume that Glisson was the single most important source for Baxter's views on medical spirits. ${ }^{80}$ Indeed, Glisson's opinions are drawn upon right at the beginning of the first letter to More:

I think you and I are agreed that we cannot conceive of a Spirit unico conceptu, but must have two inadequate conceptions of it: of which one is that which Dr. Glisson De Vita Naturae calls conceptus fundamentalis, and is that which we call Substantia ... the other inadequate conceptus is Formal; and I think you and I are agreed that this is Virtus Una-tria, as described by me, viz. Virtus vitalis, vitaliter activa, perceptiva, appetitiva, as Dr. Glisson speaks. ${ }^{81}$

More's response to this was to argue that from these two inadequate conceptions of spirit "one adequate Conceptus does result" but, thankfully, we do not have to pursue the philosophical niceties of this typical piece of seventeenth-century theology. Suffice it to say that More immediately recognized the danger implicit in Baxter's Glissonian approach, "[which] is not only a mistake but a mischief, it implying that the Virtus Appetitiva and Perceptiva, may be in a substance though Material which betrays much of the succours that Philosophy affords to Religion in the points of the Existence of a God and Immortality of the Soul." 82 The safe way to salvation, More insisted, was through his own recension of Cartesian mechanism. This was a new philosphy which still fulfilled the age-old role of hand-maiden to religion: "This mode of philosophy is the most useful for the best ends, and serves to support the main parts of natural Religion the best; namely the Existence of God, of Genii or Angels, and the

\footnotetext{
${ }^{78}$ Baxter, Of the nature of spirits, op. cit., note 71 above, p. 71.

${ }^{79}$ Richard Lower, Diatribae Thomae Willisii ... de fehribus vindicatio.... London, J. Martyn and J. Allestry, 1665, p. 117; see also pp. 23, 89-107, 110, 114-127. This has been reprinted with a translation as: Kenneth Dewhurst (editor), Richard Lower's Vindicatio: a defence of the experimental method, Oxford. Sandford Publications, 1983. There would seem to be a lot in common between Willis's pyretology and Baxter's "psychopyrism". For similar ideas see Mendelsohn, op. cit., note 77 above; R. G. Frank, Harv'?' and the O.xford physiologists: a study of scientific ideas and social interaction. Berkeley, University of California Press, 1980; Douglas McKie, 'Fire and the flamma vitalis: Boyle. Hooke and Mayow', in Underwood (editor), op. cit., note 3 above, vol. 1, pp. 469-488; Mani, op. cit., note 6 above; A. G. Debus, 'Chemistry and the quest for a material spirit of life in the seventeenth century', in Fattori and Bianchi (editors), op. cit., note 3 above, pp. 245-263.

${ }^{80}$ There is evidence to suggest that Baxter and Glisson were acquainted. See below, notes 95 and 96.

${ }^{81}$ Baxter, Of the nature of spirits, op. cit., note 71 above, sig. A2r/v. For “inadequate conceptions" see Glisson, op. cit., note 5 above, sig. a2r/v, and pp. 11-12.

82 More, Letter, op. cit., note 71 above, p. 196, 198; cf. also p. 217.
} 


\title{
J. Henry
}

Immortality of the Soul." To deny this, he continued "deprives us of some of the most considerable aids that Philosophy affords against Atheism and Epicurism." 83

For his part, Baxter was just as sensitive as More to anything that might threaten sound religion. He had, therefore, added a qualification to his citation of Glisson: "And yet I dare not say that a self-moving principle is proper to a Spirit. Nor do I consent to Campanella de sensu rerum, and Dr. Glisson that would make all things alive by an essentiating form in the very Elements." ${ }^{84}$ The point of Baxter's qualification, as he later spelled out, was that it is wrong to propose activity or life in matter as a necessary or natural attribute but that there is no logical contradiction in the concept of living, perceiving matter. As he himself put it;

\begin{abstract}
I confess I am too dull to be sure that God cannot endue matter itself with the formal virtue of Perception: That you say the Cartesians hold the contrary, and that your writings prove it, certifieth me not ... That Almighty God cannot make perceptive living Matter, and that by informing it without Mixture [i.e. without adding a separate active substance to it], I cannot prove, or I think you: Where is the Contradiction that makes it impossible?
\end{abstract}

It is perhaps indicative of Baxter's philosophical sophistication that this same point was made nearly ten years later by John Locke in his Essay concerning human understanding. ${ }^{86}$ Also worthy of Locke is Baxter's denial of the essential dichotomy of body and spirit on the grounds that all we can know are the modifications of substances, not the substances themselves, because we learn everything through sensation or perception.

\begin{abstract}
For to tell you the truth [Baxter writes], I know nothing at all without the mediation of sense except the immediate sensation itself, and the acts of Intellection, Volition or Nolition, \& what the Intellect infereth of the like, by the perception of these ... Now hence I infer, that I have no sense at all of the difference of a Spirits Substantiality in such modes and accidents from that of Matter, and therefore how can I know it?
\end{abstract}

The crucial difference between More and Baxter should now be abundantly clear. More, in spite of his many disagreements with Descartes, was always totally committed to the dualist distinction between body and soul (or spirit). Baxter, on the other hand, seems to have had a much clearer sense of the philosophical shortcomings of any dualist system. ${ }^{88}$ By insisting so vigorously on the categorical difference between body

${ }^{83}$ Ibid., p. 225.

${ }^{84}$ Baxter, Of the nature of spirits, op. cit., note 71 above, sig. A3r.

${ }^{85}$ Ibid., pp. 28-29. Baxter is referring to More, Letter, op. cit., note 71 above, p. 198.

${ }^{86} \mathrm{John}$ Locke, An essay concerning humane understanding, London, Eliz. Holt for Thomas Basset, 1690. bk. 4 , ch. 3, sect. 6 . For a full discussion of this aspect of Locke's philosophy see Yolton, op. cit., note 52 above, especially pp. 14-28.

87 Baxter, $O$ of the nature of spirits, note 71 above, p. 15.

88 I am unaware of any extended historical analysis of the fortunes of dualist and monist philosophies but there is a good brief account of the reaction to Cartesian dualism in R. A. Watson. The downfall of Cartesianism 1673-1712: a study of epistemological issues in late seventeenth-century Cartesianism. The Hague. Martinus Nijhoff, 1966, especially pp. 105-121, 147. There is much that is germane to the background of seventeenth-century monism in Norman T. Burns. Christian mortalism from Tindale to Milton, Cambridge, Mass., Harvard University Press, 1972. For the end of the century and the story through the eighteenth, see Yolton, op. cit., note 52 above. There was frequent affiliation between monism and 


\section{Medicine and pneumatology}

and soul, More found it impossible to give any plausible account of their interaction. Whenever he abandoned rhetoric and seriously tackled the problem, he had to resort to a concept of spirit which was every bit as materialistic as Baxter's "psychopyrism" (as Baxter himself was quick to point out). ${ }^{89}$ Baxter, steeped in voluntarist theology, was content to take a monistic solution to the soul-body problem because he believed God, by his will, could endow matter with the attributes of life, perception, and automotion. However, the seventeenth-century reader was always quick to equate monism with atheism (as reactions to Hobbes and Spinoza clearly indicate) and so Baxter's $O f$ the nature of spirits is sprinkled with apologetic non-dogmatic expressions of his views. ${ }^{90}$ Nevertheless, it remains clear that Baxter is in the tradition of neo-Platonic writers who characterized the system of the World in terms of a hierarchy of forms, descending from the "purely immaterial" (God) through successively less-tenuous material entities like light, aether, fire, and air down to the crass material of earthy substances. ${ }^{91}$ In this tradition, fire, being one of the most tenuous and subtle of material substances, is frequently regarded as holding an intermediate position between the sub-lunary world and the higher realm of "pure spirits". By the same token, fire can be equated with the human soul which also holds this intermediary position. ${ }^{92}$ It is this neo-Platonic tradition which provides the context for Baxter's rejection of the mechanistic account of fire to which More subscribes. Baxter does not mince his words:

medical theories. On this see the works by Walker and Pagel cited in note 3 above, and Walter Pagel, The similing spleen: Paracelsianism in storm and stress, Basle, Karger, 1984, pp. 105-108, 148, 156.

${ }^{89}$ On this see Walker, 'Medical spirits in philosophy', op. cit., note 3 above, pp. 289, 293-296; and Henry. op. cit., note 30 above. See also Baxter, $O$. f the nature of spirits, op. cit., note 71 above, sig. A6v, pp. 47-49, 64 . 66,91 , and 95-97.

${ }_{90}$ For example, Baxter admitted that when he tried to define the differences between substance and matter he was "at a loss" (sig. A3v), that Glisson's way was merely "as probable" as More's (p. 6) but that he himself preferred to take "the middle way" (p. 7), and still remained content "with an ignoramus" on other issues (p. 21). Further evidence for the contemporary reluctance to adopt a monist philosophy is provided by Baxter's statement that he was not an easy convert to the notion of a "Virtue una-trina, vitali, perceptiva, appetitiva" in substance: "Nor did I easily assent to it; nor did Dr. Glisson after 80 years of age, easily procure men to assent to it" (p. 25). As far as I know, Baxter's voluntarist theology has not been noticed before, but for indications of the vigour of this kind of theology in seventeenth-century England, see Francis Oakley, 'Christian theology and the Newtonian science: the rise of the concept of the laws of nature'. Church History, 1961, 30: 433-457; J. E. McGuire, 'Boyle's conception of nature', J. Hist. Ideas, 1972, 33: 523-542; and Eugene M. Klaaren, Religious origins of modern science: belief in Creation in seventeeth-century thought, Grand Rapids, Mich., W. B. Eerdmans, 1977, pp. 29-52.

${ }_{91}$ On this see Crombie and Lindberg, both cited in note 43 above; as well as A. H. Armstrong, The architecture of the intelligible universe in the philosophy of Plotinus: an analytical and historical study, Cambridge University Press, 1940; Kurt Goldammer, 'Lichtsymbolik in philosophischer Weltanschauung. Mystik und Theosophie vom 15. bis zum 17. Jahrhundert', Studium Generale, 1960, 13: 670-682; P. O. Kristeller, The philosophy of Marsilio Ficino, New York. Columbia University Press, 1943; and E. E. Maechling, 'Light metaphysics in the natural philosophy of Francesco Patrizi da Cherso', MPhil thesis. University of London, 1977.

92 This is a prevalent notion and forms the background to the confusion between medical spirits and the soul as described by Walker in the works cited in note 3 above, and suggested in the works by Mendelsohn, Frank, McKie, and Mani cited in note 79 above. Perhaps the clearest example is to be found in the metaphysics of Francesco Patrizi da Cherso, see Maechling, op. cit., note 91 above: and Benjamin Brickman. An introduction to Francesco Patrizi's 'Nova de universis philosphia', New York. Columbia University [PhD thesis], 1941. 


\section{J. Henry}

I had as willingly have heard Cartesius tell me any dream else that ever came into his Brain: For this I greatly despise: And wonder not that any man is ignorant of the nature of Spirits, who is so grossly ignorant of the igneous analogical Nature as he was ... Really when I read how far you have escaped the delusions of Cartesianism, I am sorry that you yet stick in so gross a part of it as this is; when he that knoweth no more than motion in the Nature of Fire, which is the active principle by which mental and sensitive Nature operateth on Man, and Bruits and Vegetables, and all the passive Elements, (if it be not ipsa forma telluris) and all the visible actions in this lower World are performed, what can that mans Philosophy be worth? I therefore return your Counsel, study more thoroughly the Nature of Aethereal Fire. ${ }^{93}$

The association of this neo-Platonic tradition with medical theories about the nature of spirits, to which D. P. Walker has alerted us, can now be seen to be fundamental to Richard Baxter's pneumatology. Glisson, however, did not need to single out fire as the active principle in nature since he held all matter to be more or less active. As Glisson was evidently Baxter's major source, it is hardly surprising that we find Baxter equivocating between spirit as fire or as substance endowed by God with perceptive, appetitive, and motive faculties. ${ }^{94}$ In spite of this ambiguity one thing is clear; Baxter's theology was strongly influenced by current medical theories.

\section{CONCLUSIONS}

There is evidence to suggest that Richard Baxter was personally acquainted with Francis Glisson who was physician (as Baxter himself tell us) to his close friend and neighbour, Sir Matthew Hale. ${ }^{95}$ This would explain Baxter's familiarity with Glisson's philosophical ideas. But Baxter himself believed that familiarity with Glisson's philosophy was rare. He was even unaware of More's attack on Glisson in the Epistola altera since he admonished More:

I marvel that when you have dealt with so many sorts of Dissenters you meddle not with so subtile a piece as that old Doctor's de Vita Naturae: I have talkt with divers high pretenders to Philosophy here of the new strain, and askt them their judgement of Dr. Glissons Book, and I found that none of them understood it, but neglected it as too hard for them, and yet contemned it. ${ }^{96}$

More, naturally enough, was delighted to put his adversary right. In his anonymous commentary on Bishop Rust's Discourse of truth, More said of himself

that the Doctor has not only read that subtile Piece of Doctor Glissons, but understands so thoroughly his Hypothesis, that he has solidly and substantially confuted it. Which he did in a faithful regard to Religion. For that Hypothesis, if it were true, were as safe, if not a safer Refuge

\footnotetext{
${ }^{93}$ Baxter, Of the nature of spirits, op. cit., note 71 above, pp. 57-59. Baxter is returning More's counsel because More had urged Baxter to abandon his neo-Platonic view of fire in favour of the Cartesian account. See More, Letter to a learned psychopyrist, op. cit., note 71 above, pp. 226-230.

${ }_{94}$ For instances of this equivocation see Baxter, Of the nature of Spirits, op. cit., note 71 above, sig. A3r, and p. 10, but the whole discussion reflects Baxter's uncertainty (as he freely admitted, see note 90 above).

${ }_{95}$ The friendship between Baxter and Hale was documented in Richard Baxter, Additional notes on the life and death of Sir Matthew' Hale, London, for Richard Janeway, 1682, reprinted in Hale, op. cit., note 73 above. While describing Hale's death. Baxter tells us that "When he found his belly swell, his breath and strength much abate, and his face and flesh decay, he cheerfully received the sentence of death: and though Dr. Glisson, by mere oximel squilliticum, seemed awhile to ease him, yet that also soon failed him ... p. 92 . (Oximel squilliticum is a composition of vinegar flavoured with squills or sea-onions and honey; it is intended to be both diuretic and expectorant.)

${ }^{96}$ Baxter, Of the nature of spirits, op. cit., note 71 above, p. 6 .
} 


\section{Medicine and pneumatology}

for Atheists, then the mere Mechanick Philosophie is:... But God be thanked Dr. H. More ... has perfectly routed that fond and foul Hypothesis of Dr. Glisson, and I dare say is sorry that so good and old a Knight errant in Theologie and Philosophie as Mr Richard Baxter seems to be, should become benighted, as in a wood, at the Close of his daies, in this most horrid dark Harbour and dismal Receptacle or Rendezvous of wretched Atheists. ${ }^{97}$

The time is long overdue for a further reappraisal of Glisson's influence. Arrigo Pacchi, in his survey Cartesio in Inghilterra, has said that contemporaries reacted to Glisson's philosophy with "almost total silence" ${ }^{98}$ However, as we have seen, three of the leading theologians in England, Baxter, More, and Cudworth, responded forcefully to his work. Henry Oldenburg gave a careful review of the De natura substantiae energetica in his Philosophical Transactions and Robert Boyle regarded it as sufficiently threatening to his own natural philosophical enterprise to make it a target for criticism in his Free inquiry into the vulgarly receiv'd notion of nature.$^{99}$ There are strong indications, also, that Glisson's philosophical ideas influenced Leibniz and Locke, though the evidence has yet to be properly assessed. ${ }^{100}$ It is clear, at any rate, that Glisson's views were not dismissed by contemporaries as the irrelevant ramblings of a dotard, but were noticed as an important new system of philosophy.

One final point should be re-emphasized. I have argued that medical theories played an important role in the pneumatology of Henry More and Richard Baxter. More responded in his writings to Harvey, Wharton, and Regius as well as Glisson, and he even adapted J. B. van Helmont's concept of archeus for his own use. Baxter drew many of his beliefs about the nature of life and the soul from Jean Fernel, the neo-Platonizing medical tradition of "psychopyrism", to retain More's apt neologism, and the philosophy of Francis Glisson. ${ }^{101}$ The importance of such medical concerns for contemporary developments in philosophical theology, therefore, should not be underestimated. I hope I have shown, also, that Glisson's one and only

\footnotetext{
${ }^{97}$ More, Digression, note 72 above, pp. 192-193. More obviously went to some trouble to introduce the puns into this piece, it would be a pity if the reader missed them.

${ }^{98}$ Pacchi, op. cit., note 52 above, p. 151.

99 Phil. Trans., 1672, 7: 5076-5077. Robert Boyle, A free enquiry into the vulgarly receiv'd notion of nature, London, H. Clark for John Taylor, 1658/6. The major targets for Boyle's attack were latter-day Aristotelians and the Cambridge Platonists. See McGuire, op. cit., note 90 above. What has not been noticed so far is that Boyle was also concerned to argue that "Inanimate bodies can have neither Appetites nor Hatreds" (p. 268). It has been suggested that Boyle was also attacking a specific group of "pagan naturalists" in this work but evidence for this is tendentious, see J. R. Jacob, 'Boyle's atomism and the Restoration assault on pagan naturalism', Social Studs. Sci, 1978, 8: 211-233.

${ }^{100}$ For his influence on Leibniz see Sprengel and Rémusat, both cited in note 6 noted above: and H. Marion, Franciscus Glissonius quid de natura substantiae seu vita naturae senserit et utrum Leibnitio de natura substantiae cogitanti quidquam contulerit, Paris, G. Baillière, 1880.

${ }^{101}$ More, Immortality, mentions Regius, for example, at 79, 92, 96; Wharton at 93-94; and J. B. van Helmont at 79-80, 171, 174, and 195. Harvey appears in the notes to the 4th ed., note 39 above, pp. 97, 127. More uses Helmont's concept of archeus in the notes to his poem, Psychozoia, see Grosart (editor), op. cit., note 29 above, p. 139; and in the notes to the 4th ed. of the Immortality of the soul, note 39 above, p. 10, and elsewhere throughout his works. Jean Fernel is cited by Baxter in his Methodus theologiae christianae .... note 70 above, p. 176. Baxter also had a copy of Fernel's Universa medicina, Paris, 1567, in his personal library. Indeed, there were a significant number of medical books in his library but only one work by Glisson: Anatomia hepatis. For the complete list of Baxter's book collection see Geoffrey F. Nuttall, 'A transcript of Richard Baxter's library catalogue; a bibliographical note', J. Ecclesiastical Hist., 1951 and 1952, 2: 207-21; and 3: 74-100. There is a concentration of medical works at 3: 94-95.
} 


\section{J. Henry}

"philosophical" book cannot be dismissed as merely a physician's dilettantish excursion out of his own field into philosophy, which adds nothing to my claim that medical concepts were important to contemporary philosophy. When Glisson wrote, there was no sharp distinction, as there is today, between philosophy and science, or rather philosophy and natural philosophy. Moreover, it should not be forgotten that Glisson's system of philosophy was specifically and quite explicitly developed to provide the underpinning for his medical ideas on the irritability or natural perception of tissue even where there are no nerves or sensory organs present. Glisson's Treatise on the energetic nature of substance, therefore, was a new system of philosophy which grew directly out of the pioneering physiological work pursued by one of Harvey's most able successors. In view of the contemporary recognition of the importance of medical theories to a crucial philosophical debate about the nature of the soul and the validity of dualism, it was inevitable that Glisson's medical philosophy should strike leading thinkers as a work of fundamental importance. 